\title{
The dialogical approach: education for critical consciousness
}

\section{Rabah Halabi ${ }^{\mathbf{a}}$}

${ }^{\mathrm{a} O r a n i m}$ College, Israel

\begin{abstract}
In this paper I will try to present an alternative approach to teacher-training that is based on the Freirian dialogic approach. The goal of this approach is to raise the students' awareness of the reality in which they live and to provide them with tools for critical analysis of that reality. Instruction that is based on respect for the students and on belief in the capacities and knowledge that they bring with them is instruction that combines the students' personal experiences with the study of existing theory in the field. The combination of personal experience and theory leads to the production of new knowledge. In this paper I describe my personal experience as a lecturer in the Oranim Academic College of Education in Israel. The description includes an explanation of the courses, the manner of instruction, the topics addressed, the main issues that come up as the students bring their experiences to the classroom, the students' response to the courses and my own perspective of this experience: what can be learned from it and how it can be applied.
\end{abstract}

Keywords: Dialogue, Critical Education, Teacher-training, Students 


\section{Introduction}

For the past five years I have been trying to develop a dialogic teaching approach in the Oranim College. I had been captivated by this approach ever since I first came across the writings of Paulo Freire. I applied the dialogic approach for many years while conducting Jewish-Arab dialogue work in Wahat al-Salam / Neve Shalom. There we conducted Jewish-Arab dialogue in small groups and in this forum it was relatively easy to apply Freire's dialogic principles. However in a conventional classroom where the students are accustomed to frontal teaching and where they regard the lecturer as the sole source of knowledge, applying the dialogic approach is a much greater challenge. At first I encountered difficulties from students who seemed suspicious of the approach as well as difficulties stemming from my own lack of confidence in this innovative method. As time went on the work flowed more easily and succeeded well beyond my expectations.

In this paper I would like to share with the readers my experience as a "dialogic lecturer," addressing both the successes as well as the obstacles that I met along the way. I begin with a brief presentation of the dialogic approach as it appears in Freire's writing and afterwards I will describe the structure and process of a dialogic lesson. I will describe the difficulties that I encountered in conducting these lessons and finally I will present the students' attitudes towards these lessons as expressed in lesson summaries and in the feedback that they gave in the framework of the college's evaluation.

\section{Freirian Dialogue}

Paulo Freire, one of the founders of critical pedagogy, claimed that humanization has been the central challenge throughout our history:

While both humanization and dehumanization are real alternatives, only the first is the people's vocation. This vocation is constantly negated, yet it is affirmed by the very negation. It is thwarted by injustice, exploitation, oppression, and the violence of oppressors, it is affirmed by the yearning of the oppressed for freedom and justice, and by their struggle to recover their lost humanity. ( Freire and Macedo, 2000, P 45).

Freire (1982) goes on to claim that the education system is usually an oppressive system acting to preserve the status quo and serve the ruling elite. Schooling, Freire writes, is based on a "banking" concept in which the teacher "deposits" knowledge into the students' "accounts" in order to "withdraw" that knowledge at a later time. The underlying and actual purpose of the banking concept is to maintain a social structure that is based on 
oppressors and oppressed. By undermining the students' critical and creative capacities, banking education serves the interests of the hegemonic group that benefits from the existing social order.

In order to liberate the student, a dialogic pedagogy must be implemented in the schools with the goal of raising the students' awareness of their situation. They must be enabled to reach an awareness of the oppressive reality in which they live, of the reasons for their oppression and of the options for liberation. Only through consciousness, says Freire, can a person act in the world in order to change it. Only through "praxis," the combination of consciousness and action towards change, can a people achieve their vocation of humanization (1970).

The dialogue according to Freire (1992) is not a mechanical discussion conducted by taking turns in the classroom, nor is it a psychological discourse aimed at making the students feel good without changing the reality. The dialogue is interaction between the teacher and her students through which everyone takes part in creating new knowledge. The dialogue begins with the participants' personal experience and, through the educational process, leads them to apply theory that enables them to gain insight into broader social processes. Discussion of personal experience alone is not sufficient, however the students' personal experience must not be skipped over with discussion going directly to the level of theory and generalization. The dialogue is a process undertaken jointly in order to recognize, challenge and even change the reality.

Freire (2000) writes that the teacher cannot be passive in her educational work. She must be active, giving direction and presenting a path, but she must not demand of her students to take it. According to Freire the teacher cannot be objective or neutral, therefore she has two options. She can either avoid taking a stand and by doing so take part in the oppressive work of the establishment or she can express her opinion in order to expose the reality of oppression and challenge it. In the latter case the teacher must still be careful not to force her opinions on the students.

Not much on this topic appears in the literature, particularly regarding the application of a dialogic approach in an academic setting. Even less has been written about the application of the dialogic approach as expounded by Freire. The literature that does exist confirms the effectiveness of every aspect of the approach in every framework in which it is applied. Mercer \& Littleton (2007) primarily addressed theoretical aspects of dialogue and its effectiveness in classroom instruction. They cite a great deal of research proving the connection between dialogic instruction, the students' learning capacities and particularly the development of the students' thinking skills. Vella (1994) discussed the power of applying a dialogic approach in adult education, particularly in that the learner also teaches. She defines twelve principles of dialogue and demonstrates how the application of these 
principles in adult education ensures effective learning. Wallerstein \& Bernstein (1988) discussed the application of Freire's dialogic approach as an effective means of healing. They claim that participation in a dialogue group improves the participants' self-control and strengthens their belief in their ability to change their lives. They demonstrate this through a case study of an alcoholics' rehabilitation group. As mentioned above, in this article I will discuss the application of Freire's dialogic approach in the framework of an academic classroom.

\section{Dialogue experience in the classroom}

My past five years of teaching in Oranim's Academic College of Education have been guided by an attempt to apply Freire's dialogic approach presented above. I apply the approach in M.A. teacher training courses as well as in an M.A. program on inclusive education. There are usually about 20 students in a class, representing very different backgrounds. There are both Ashkenazi and Mizrahi Jewish students and sometimes there are Ethiopian Jews. There are also Arab students.

The course is divided into two parts. The first part usually consists of four lessons devoted to learning about the approach. The students not only learn the approach by reading Freire's work on the pedagogy of the oppressed and on dialogic learning; they also learn about it through the example I set, demonstrating the approach in the way that these lessons are conducted. In the second part of the course the students are given the opportunity to apply the approach. Ten students are invited to conduct a lesson putting the dialogic approach into action.

The lessons conducted by the students are divided into two parts. In the first part each student teaches a 45-minute lesson as is given in the high school. In the second part we analyze the lesson, examining the extent to which it was in fact conducted through Freire's dialogic approach and where the student's difficulties lay in applying the approach. The student-teacher himself is given the opportunity to open the analytical part of the discussion, sharing his experience with the class and evaluating his own work. This is followed by contributions from the other students and from me as we work together to evaluate the lesson with the aim of learning from each one's successes and difficulties.

It must be noted that the students have the right to choose the topic that they wish to teach. Most of the students choose socio-political or educational topics that concern them. Among the topics chosen over the years were: discrimination against Mizrahi Jews, the status of women, the Arab education system, the social reality of peripheral as opposed to central regions of the country, the Druze in Israel, excluded students, racism in Israeli society, the implications of teachers' approaches and attitudes for the fate of their students, 
multicultural education etc. Each topic is introduced by presenting something that evokes a response such as a short film, a newspaper article or anything else that the student chooses in order to start the lesson.

As mentioned above, the students learn about the approach through their own practice and experience and through that of their peers. By working together through the dialogic approach the students also gain new insight and expand the knowledge in a variety of fields. This knowledge is usually produced in the students' presentations, but it also stems from the dialogue through which students share their personal experiences with each topic.

I can point out a number of issues from my experience that commonly arise in these lessons. The first one is the student teachers' difficulty of dealing with silence - even a short silence of a few seconds. The student-teachers tend to fill each moment of silence with their own speech, blocking the other students' opportunities to take part in the lesson and express their opinions. In analyzing the lessons the student- teachers speak of the difficulty of remaining silent. They are not accustomed to silence in the classroom and they express concern that the other students may interpret their silence as an indication that they have nothing to say and as a sign of weakness. On the other hand the students in the class often say that had the student-teacher waited a bit more, they would have had time to organize their thoughts and contribute to the discussion.

The second issue is the student-teacher's difficulty of addressing points that the students try to stress when they share their experiences. The student-teacher at first finds it difficult to relinquish control over the agenda and allow true dialogue to take place. While ostensibly inviting dialogue, they actually find it difficult to free themselves from a frontal approach through which they attempt to steer the students towards the particular discussion that they, the student-teachers, wish to conduct. In other words they force their agenda on the students creating a frontal lesson that is merely disguised as dialogic.

The last issue has to do with the student-teacher expressing an opinion. Most of the students who conduct lessons still maintain a belief in the narrative that the teacher must be objective and neutral. The expectation of them to take a stand regarding the topic that they bring is very difficult for many of them. When analyzing the lesson they speak of the trouble they had deciding what they can say, what they cannot say and at what point they should express an opinion and share their own experiences, if at all. 


\section{Students' Feedback}

Over the years the feedback that the students gave both in the summaries of the courses and in the evaluations conducted by the college has been very positive. The students expressed their appreciation of the opportunity that they had to express themselves and they noted the diversity of the material that was introduced into the classroom as a result. Below are a number of quotes from some of the feedback that reflect the students' experience.

One student summarized the course as follows: "This was one of the most interesting courses that I took in all of my university studies. It enabled us to conduct constructive dialogue in a clear and successful manner. We had the opportunity to express ourselves, in contrast to almost all of the other courses that were based strictly on the research literature. This course included everything."

Another student continued in this direction, explaining the uniqueness of the course and how it differs from the others: "The course was very interesting. The way in which the course was taught was very interesting because the lecturer connected the theory to our daily lives. He devoted time to teaching the theory and most of the lesson involved discussion and our own comments. That was almost the first time that I felt that I truly knew what we were talking about in a course, without reviewing the course summaries! I would recommend that this be a mandatory course for all of the students in the college."

One of the positive points that the students repeatedly brought up was the connection between the theory and their reality: "The course was based on a model that I very much connected to. We studied both the theory and its practical application. I feel like I can take the principles that I learned in the course and apply them in my work."

The opportunity that the students had to experience teaching a lesson during the course contributed to their ability to connect theory to practice: "I learned another way to conduct a lesson. The very fact that the students were given an opportunity to conduct a 45-minute lesson to other students in the class gave me the experience of conducting this kind of lesson. Moreover, I learned to deal with different situations that can arise when teaching a lesson like that".

These courses opened the participating Jewish and Arab students to issues regarding relations between the two peoples and regarding the conflict that shapes much of the reality in which they live: "The course was very interesting. It's a course that enables a positive meeting between Arabs and Jews and creates a good space to conduct dialogue about every aspect of the conflict between Arabs and Jews. It exposed us to topics that were so interesting and it exposed me in particular to things that I never knew. It was interesting to see the two sides talking, with everyone presenting his perspectives." 
Continuing in that vein another student said: "A unique course like nothing I ever came across in the college. The course enlightened me in the best possible way about the IsraeliPalestinian conflict. It provided a real opportunity to create dialogue between two groups in conflict. I have to point out that I have many friends from both groups and in this course I heard opinions that I had never heard before. I was happy to hear and learn about the other's narrative in an authentic manner".

Regarding the conflict and Jewish-Arab relations, Arab students, both male and female, reported that the course provided them with an experience that they had never before had, neither within the academic setting nor outside of it - the experience of expressing themselves without fear or concern: "During the course I made a conscious effort to express critical opinions and not just be content with remaining silent. I was brought up to be proud of my Palestinian identity, but not openly, for fear that expressing my opinions would close doors to me. In school I was not taught to try to create the world that I would like to see, nor to develop an ideology reflecting things as I see them and I certainly was not given tools for critical examination of my reality. Here I felt safe to express myself and say my opinion out loud."

These courses clearly strengthened and empowered the Arab students: "The truth is, I felt that this lesson is my place to express my difficulties and frustrations regarding all of the issues that disturb me as a member of the Arab minority in Israel. The State and the establishment oppress us and we cannot express ourselves - not in the schools and not in our reality outside. Here I felt safe and I had the confidence to criticize the establishment and raise my feelings of frustration and disappointment. I leave this course feeling strengthened with thoughts about how to take what I learned here and apply it with my own students."

Discussing their experience with the course, several other students also brought up their thoughts about how to apply in their own classrooms what they learned: "When I look ahead to the way in which I want to teach, I think that this course gave me a more complex understanding, enabling me to see the importance and significance of the teacher's work with the students. How important it is to come to the class with broad knowledge and a clear position together with an ability to learn from my students about where they come from, what world that they bring to the classroom and then to help them develop their own perceptions through research and study."

The question of transferring the knowledge they acquired to the field and to the school after they become teachers preoccupied a large number of students: "During the course I kept asking myself the same question. Will I succeed in my task? Can I really create for my students a place that accepts them and listens to them, enabling them to enter dialogue that develops thinking and that raises new points to think about? I have to say that developing 
the ability to hear things that go against your opinion, without trying to change the other's opinion or even influence it, is no easy task."

Some of the students began to apply the principles that they learned through exercises that they did during their participation in the course: "Of all of the courses that I took in this program, this was one that contributed to me and accompanied me throughout my teaching experience in the school. I tried the best I could to apply insights from Freire's theory and method of dialogic learning. And that was in order to prove to myself that it is in fact possible to work differently and that there is a place for educational dialogue in the formal educational frameworks - despite the strict supervision in the school system."

\section{Conclusions}

To conclude this experience, the lessons are usually very lively with much broader participation than that which characterizes the other lessons conducted in a more frontal format. The Arab students, who tend to be less active in other lessons, also find in this course a channel encouraging them to express themselves. The students report on these lessons as a significant experience and as a unique exposure to an approach that is very different from what they learn elsewhere in the college.

While the dialogic approach is actually very difficult to apply in the school, the students' exposure to its principles can enrich them, opening their eyes to aspects of their work of which that they may not otherwise have been aware. For example it turns the students' attention to the importance of respect for their students' and for the knowledge that they bring, the importance of allowing the students to express their positions in class and also the need for the teachers to make their opinions known regarding the topic being taught.

To sum up this experience, which is still in its infancy in the college, resonates loudly in the M.A. courses that I teach. The students often report that their experience in the course is unlike anything else that they encountered during their studies. I personally leave each of these courses feeling strengthened and empowered. Each course and each student teaches me something new about the approach itself and about the educational, social and political phenomena that the students bring to the discussion in the lessons. Furthermore the dialogic approach has a socio-political statement in that it offers a way to deal with the mass of knowledge in our world. While the students are easily exposed to knowledge, they are more likely to require tools for critical reading of the knowledge that swamps them from every direction. 


\section{References}

Freire, P. (1970). Pedagogy of the Oppressed. New York, Continuum.

Freire, P. (1976). Education, the practice of freedom. London, Writers and Readers Publishing Cooperative.

Freire, A., \& Macedo, D. (2000). Paulo Freire Reader .New YORK: Continuum.

Freire,p., \& Macedo, D. (2000) A Dialogue: Culture, Language, and Race. Harvard Educational Review 377-403.

Mercer, N., Littleton, K. (2007). Dialogue and the development of the children's thinking: A sociocultural approach. London and Ney York: Routledge.

Vella, J.(1994). Learning To Listen, Learning To Teach. The Power of Dialogue in Educating Adults. Jossey-Bass Higher Adult Education Series. San Francisco: JosseyBass.

Wallerstein, N., Bernstein, E. (1988). Empowerment Education: Freire's Ideas Adapted to Health Education. Health Education \& Behavior, Vol 15(4) 123-136. 